\title{
Impaired Lymphocyte Responses in Pediatric Sepsis Vary by Pathogen Type
}

\author{
Robert B. Lindell, MD ${ }^{1,2,3}$, Donglan Zhang ${ }^{1,4}$, Jenny Bush, $\mathrm{RNC}^{1}$, Douglas C. Wallace, PhD ${ }^{4,5}$, \\ Joshua D. Rabinowitz, MD, $\mathrm{PhD}^{6}$, Wenyun Lu, $\mathrm{PhD}^{6}$, E. John Wherry, $\mathrm{PhD}^{2,7,8}$, Scott L. Weiss, \\ MD, $\mathrm{MSCE}^{1,3,4}$, Sarah E. Henrickson, MD, $\mathrm{PhD}^{2,9}$
}

${ }^{1}$ Division of Critical Care Medicine, Department of Anesthesia and Critical Care Medicine, Children's Hospital of Philadelphia and the University of Pennsylvania Perelman School of Medicine, Philadelphia, PA;

${ }^{2}$ Institute for Immunology, University of Pennsylvania Perelman School of Medicine, Philadelphia, PA;

${ }^{3}$ Pediatric Sepsis Program, Children's Hospital of Philadelphia, Philadelphia, PA;

${ }^{4}$ Center for Mitochondrial and Epigenomic Medicine, Children's Hospital of Philadelphia, Philadelphia, PA;

${ }^{5}$ Division of Human Genetics, Department of Pediatrics, Children's Hospital of Philadelphia and the University of Pennsylvania Perelman School of Medicine, Philadelphia, PA;

${ }^{6}$ Department of Chemistry, Princeton University; Princeton, NJ;

${ }^{7}$ Department of Systems Pharmacology and Translational Therapeutics, University of Pennsylvania Perelman School of Medicine, Philadelphia, PA;

${ }^{8}$ Parker Institute for Cancer Immunotherapy, University of Pennsylvania Perelman School of Medicine, Philadelphia, PA;

${ }^{9}$ Division of Allergy and Immunology, Department of Pediatrics, Children's Hospital of Philadelphia and the University of Pennsylvania Perelman School of Medicine, Philadelphia, PA 


\section{Corresponding author:}

Robert B. Lindell, MD

Assistant Professor of Critical Care and Pediatrics

Department of Anesthesiology and Critical Care Medicine

University of Pennsylvania Perelman School of Medicine

Children's Hospital of Philadelphia

3401 Civic Center Blvd.

Philadelphia, PA 19104

Phone: 267-426-3126

Email: LindellR@chop.edu

\section{Sources of Funding:}

Financial support was provided by the Endowed Chair, Department of Anesthesiology and Critical Care, Children's Hospital of Philadelphia and the University of Pennsylvania Perelman School of Medicine. Dr. Lindell is also supported by the Thrasher Research Fund \#15351. Dr.

Wallace is also supported by NIH grants NS021328, MH108592, and OD010944, U.S.

Department of Defense grants W81XWH-16-1-0401 and W81XWH-21-1-0128, (PR202887.e002). Dr. Wherry is also supported by the Parker Institute for Cancer Immunotherapy which supports the cancer immunology program at UPenn, and by NIAID AI155577, AI115712, AI117950, AI108545, AI082630. Dr. Weiss is also supported by NIGMS

K23GM110496 and NICHD R01HD102396. Dr. Henrickson is also supported by NIAID K08AI135091, the Burroughs Wellcome Fund CAMS, the Clinical Immunology Society, and the American Academy of Allergy, Asthma, and Immunology. 
medRxiv preprint doi: https://doi.org/10.1101/2021.09.15.21263652; this version posted October 29, 2021. The copyright holder for this preprint (which was not certified by peer review) is the author/funder, who has granted medRxiv a license to display the preprint in perpetuity.

All rights reserved. No reuse allowed without permission.

Word count: 240 (abstract), 3357 (manuscript)

Key words: Sepsis, pediatric, T cell, immunoparalysis, flow cytometry, cytokine, mitochondria, metabolomics
ABBREVIATIONS
PBMC Peripheral blood mononuclear cells
PIM-2 Pediatric Index of Mortality-2
PRISM-III Pediatric Risk of Mortality-III
PELOD Pediatric Logistic Organ Dysfunction
LPS Lipopolysaccharide
HLA-DR Human leukocyte antigen - DR isotype
SRC Spare respiratory capacity
PMA Phorbol myristate acetate
Th1 cell Type $1 \mathrm{CD} 4^{+} \mathrm{T}$ helper cell
Th2 cell Type $1 \mathrm{CD} 4^{+} \mathrm{T}$ helper cell
Th17 cell Type $1 \mathrm{CD} 4^{+} \mathrm{T}$ helper cell
Tfh cell $\quad \mathrm{T}$ follicular helper cell
Treg cell Regulatory $\mathrm{T}$ cell
TNF- $\alpha \quad$ Tumor necrosis factor $\alpha$
IFN- $\gamma \quad$ Interferon $\gamma$ 


\section{ABSTRACT}

\section{Background}

Sepsis is the leading cause of death in hospitalized children worldwide. Despite its hypothesized immune-mediated mechanism, targeted immunotherapy for sepsis is not available for clinical use.

\section{Objective}

To determine the association between cytometric, proteomic, bioenergetic, and metabolomic abnormalities and pathogen type in pediatric sepsis.

\section{Methods}

Serial PBMC samples were obtained from 14 sepsis patients (34 samples) and 7 control patients for this pilot study. Flow cytometry was used to define immunophenotype, including T cell subset frequency and activation state, and assess intracellular cytokine production. Global immune dysfunction was assessed by TNF- $\alpha$ production capacity and monocyte HLA-DR expression. Mitochondrial function was assessed by bulk respirometry. Plasma cytokine levels were determined via Luminex assay. Metabolites were measured by liquid chromatography-mass spectrometry. Results were compared by timepoint and pathogen type.

\section{Results}

Sepsis patients were older and had higher illness severity compared to controls; demographics were otherwise similar. Compared to controls, sepsis patients demonstrated global 
medRxiv preprint doi: https://doi.org/10.1101/2021.09.15.21263652; this version posted October 29, 2021. The copyright holder for this preprint (which was not certified by peer review) is the author/funder, who has granted medRxiv a license to display the preprint in perpetuity.

All rights reserved. No reuse allowed without permission.

immune dysfunction, loss of peripheral of non-naïve $\mathrm{CD} 4^{+} \mathrm{T}$ cells, and reduced PBMC

mitochondrial function. Metabolomic findings in sepsis patients were most pronounced at sepsis

onset and included elevated uridine and 2-dehydrogluconate and depleted citrulline. Loss of

peripheral non-naïve $\mathrm{CD} 4^{+} \mathrm{T}$ cells was associated with immune dysfunction and reduced

cytokine production despite increased $\mathrm{T}$ cell activation. $\mathrm{CD} 4^{+} \mathrm{T}$ cell differentiation and

corresponding pro- and anti-inflammatory cytokines varied by pathogen.

\section{Conclusion}

Pediatric sepsis patients exhibit a complex, dynamic physiologic state characterized by immunometabolic dysregulation which varies by pathogen type. 


\section{MAIN TEXT}

\section{Introduction}

Pediatric sepsis is the leading cause of death in hospitalized children worldwide. ${ }^{1}$ As in adults, sepsis in children is characterized by concurrent pro- and anti-inflammatory states with dysregulation of the innate and adaptive immune response to infection. ${ }^{2,3}$ Critical care for sepsis is limited to antibiotics, source control, and supportive care for organ dysfunction. ${ }^{4}$ Immunocompromised patients and those who develop immune suppression in the setting of sepsis both represent high-risk clinical phenotypes, with mortality rates that exceed $50 \%{ }^{5,6}$ Despite a hypothesized immune-mediated mechanism, successful interventional trials of targeted immunomodulation in sepsis remain elusive. ${ }^{7}$

Previous investigations have demonstrated that focused measures indicative of innate and adaptive immune dysfunction ${ }^{8-10}$ are associated with secondary infection, ${ }^{11}$ persistent organ dysfunction $^{12}$ and mortality ${ }^{5,6,13}$ in pediatric sepsis, however comprehensive analyses of immunometabolic changes are lacking and could yield therapeutic insights for these high-risk patients. Advances in immune profiling have the potential to allow new insights into the role that lymphocytes play in shaping the immune response to sepsis. ${ }^{14-16}$ Here we report on a singlecenter prospective, observational study of immunometabolic function in children with sepsis in which we identified sepsis-associated immune dysregulation which varied by pathogen type through longitudinal cytometric, proteomic, bioenergetic, and metabolomic assays.

\section{Patients and Methods}

$\underline{\text { Study Design and Population }}$ 
medRxiv preprint doi: https://doi.org/10.1101/2021.09.15.21263652; this version posted October 29, 2021. The copyright holder for this preprint (which was not certified by peer review) is the author/funder, who has granted medRxiv a license to display the preprint in perpetuity.

All rights reserved. No reuse allowed without permission.

The study was approved by the Children's Hospital of Philadelphia Institutional Review Board, and written informed consent was obtained prior to any study procedures. We performed a prospective observational study of patients less than 18 years treated for severe sepsis or septic shock in a single academic PICU between May 2014 and June 2018. Severe sepsis and septic shock were defined using consensus pediatric criteria. ${ }^{2}$ Exclusion criteria were weight less than $7.5 \mathrm{~kg}$ (due to limits on blood collection), leukocyte count less than $0.5 \times 10^{3} / \mu \mathrm{L}$, known mitochondrial disease, unrepaired cyanotic heart disease, and prior study enrollment. A convenience sample of postoperative neurosurgical patients without evidence of infection or organ dysfunction were enrolled as controls.

\section{Clinical Data Collection}

Clinical data related to patient characteristics, therapies, and vital status were abstracted from each study participant. Organ dysfunction, as previously defined, was monitored for 28 days after sepsis recognition. Severity of illness was assessed by the Pediatric Index of Mortality-2 (PIM-2) score, ${ }^{17}$ Pediatric Risk of Mortality-III (PRISM-III) score, ${ }^{18}$ and Pediatric Logistic Organ Dysfunction (PELOD) score. ${ }^{19}$ Exposure to endotracheal intubation and mechanical ventilation were obtained from clinical flowsheets and physician documentation. Exposure to vasopressor infusion and steroids were obtained from the medication administration record.

\section{$\underline{\text { Biospecimen Collection }}$}

A day 1-2 sample of 7-9ml of blood was collected as soon as possible after consent and enrollment. For patients with sepsis, additional blood was collected between study days 3-5 (and 
medRxiv preprint doi: https://doi.org/10.1101/2021.09.15.21263652; this version posted October 29, 2021. The copyright holder for this preprint (which was not certified by peer review) is the author/funder, who has granted medRxiv a license to display the preprint in perpetuity.

All rights reserved. No reuse allowed without permission.

at least 2 days after first sample) and again between days 8-14 for patients who remained in the PICU. For control patients, a single sample was drawn on the date of consent and enrollment. Blood was collected in citrate tubes for measurement of mitochondrial respiration, EDTA tubes for monocyte human leukocyte antigen DR (HLA-DR) expression, and lithium heparin tubes (on ice) for measurement of whole-blood ex vivo LPS-induced tumor necrosis factor-alpha (TNF- $\alpha$ ) and plasma cytokine analyses. Mitochondrial respiration, monocyte HLA-DR, and ex vivo LPSstimulated TNF- $\alpha$ were measured on fresh blood samples. Additional peripheral blood mononuclear cells (PBMCs) and heparin plasma were isolated by density gradient centrifugation and cryopreserved at -80 degrees $\mathrm{C}$ for subsequent analysis.

\section{Flow Cytometry}

Cryopreserved PBMCs were partially thawed in a $37^{\circ} \mathrm{C}$ water bath, then resuspended in warm complete medium and plated into a 96-well round-bottom plate at a concentration of $1 \times 10^{6}$ PBMCs per well. For general immune profiling, cells were incubated with a cocktail of antibodies targeting surface proteins at room temperature for 30 minutes and then washed. After fixation and permeabilization, cells were incubated with a cocktail of antibodies targeting intracellular proteins at room temperature for 60 minutes and then washed. After staining, cells were resuspended into 1.6\% PFA fixative and held overnight at $4{ }^{\circ} \mathrm{C}$ prior to acquisition. For analysis of intracellular cytokines, PBMCs were stimulated with PMA/ionomycin for 4 hours prior to surface and intracellular staining per the above protocol.

Cells were analyzed on a LSR II flow cytometer (BD Biosciences, San Jose, CA) according to the manufacturer protocol. Single stain controls were performed with compensation beads (UltraComp Beads, Invitrogen/ThermoFisher Scientific, Waltham, MA). Compensated 
medRxiv preprint doi: https://doi.org/10.1101/2021.09.15.21263652; this version posted October 29, 2021. The copyright holder for this preprint (which was not certified by peer review) is the author/funder, who has granted medRxiv a license to display the preprint in perpetuity.

All rights reserved. No reuse allowed without permission.

FCS files were then loaded into FlowJo (Tree Star, Ashland, OR) for predefined analysis of immune cell subsets. After identification of live singlet CD3+ lymphocytes, populations of CD4 ${ }^{+}$ and $\mathrm{CD}^{+}$lymphocytes were identified through bivariate plots. Subsets of CD4+ and CD8+ cells were analyzed by CD45RA and CD27 expression using the following definitions: naïve T cell $\left(\mathrm{CD}^{2} 5 \mathrm{RA}^{+} / \mathrm{CD} 27^{+}\right)$, central memory $\mathrm{T}$ cell $\left(\mathrm{CD} 45 \mathrm{RA}^{-} / \mathrm{CD} 27^{+}\right)$, effector memory $\mathrm{T}$ cell (CD45RA $\left.{ }^{-} / \mathrm{CD}^{2} 7^{-}\right)$, and TEMRA cell $\left(\mathrm{CD}^{2} 5 \mathrm{RA}^{+} / \mathrm{CD}^{-} 7^{-}\right)$which are a subset of effector memory cells which re-express CD45RA. Non-naïve $\mathrm{CD} 4^{+}$and $\mathrm{CD} 8^{+} \mathrm{T}$ cells were defined as the union of central memory T cells, effector memory T cells, and TEMRA cells.

We then assessed CD4+ T cell differentiation by measuring intracellular cytokines via flow cytometry after PMA/ionomycin stimulation. After defining non-naïve T cells using the lineage markers and gating strategy above, we identified $\mathrm{CD} 4^{+} \mathrm{T}$ cell states based on intracellular cytokine expression: Th1 (IFN- $\left.\gamma^{+}\right)$, Th2 $\left(\mathrm{IL}_{13}{ }^{+}\right)$, Th17 (IL-17 $\left.\alpha^{+}\right)$, Tfh $\left(\mathrm{IL}-21^{+}\right)$, and Treg $\left(\right.$ FoxP $\left.^{+}\right)$. Finally, in this group we defined the activation state of these CD4+ T cell subsets by defining the IL- $2^{+}$and $\mathrm{CD} 38^{+}$cells within groups.

\section{Mitochondrial Bioenergetics}

Mitochondrial respiration was measured in PBMCs isolated from citrated whole blood by density gradient centrifugation as previously described. ${ }^{20} \mathrm{PBMC}$ cell counts were performed using trypan blue exclusion (Countess II, Life Technologies, Grand Island, NY) with median viability $88 \%$ (interquartile range 76-95\%). After isolation, the PBMC pellet was re-suspended in Hank's balanced salt solution (pH 7.40) containing $5.5 \mathrm{mM}$ glucose, $1 \mathrm{mM}$ pyruvate, and $10 \mathrm{mM}$ HEPES, centrifuged a final time at $100 \mathrm{~g}$ for 10 minutes at $20^{\circ} \mathrm{C}$, and then again re-suspended in the same "respiration buffer". Mitochondrial respiration was measured in $2-4 \times 10^{6}$ intact PBMCs 
medRxiv preprint doi: https://doi.org/10.1101/2021.09.15.21263652; this version posted October 29, 2021. The copyright holder for this preprint (which was not certified by peer review) is the author/funder, who has granted medRxiv a license to display the preprint in perpetuity.

All rights reserved. No reuse allowed without permission.

at $37^{\circ} \mathrm{C}$ using a high-resolution oxygraph (Oxygraph-2k Oroboros Instruments, Innsbruck, Austria). Oxygen flux (in pmol $\mathrm{O}_{2} / \mathrm{sec} / 10^{6}$ cells), which is directly proportional to oxygen consumption (respiration), was recorded continuously using DatLab software 4.3 (Oroborus Instruments, Innsbruck, Austria) as shown below and as previously described. ${ }^{20,21}$ Intact cells were utilized to maintain the cellular microenvironment such that respiration relied on endogenous substrates. After routine oxygen consumption was recorded for 10-20 minutes, the ATP-synthase inhibitor oligomycin $(1 \mu \mathrm{g} / \mathrm{mL})$ was added to induce a state 4-like respiration independent of mitochondrial ATP production. Under these conditions, respiration was primarily due to leakage of protons across the inner mitochondrial membrane (LEAK). Routine minus LEAK indicated ATP-linked respiration. Maximal oxygen consumption through the electron transport system (ETS) was obtained by stepwise titration (1-2 $\mu \mathrm{M})$ of the uncoupler carbonyl cyanide m-chlorophenylhydrazone (CCCP) until no further increase in oxygen consumption was detected $\left(\mathrm{ETS}_{\max }\right)$. The $\mathrm{ETS}_{\max }$ indicates the maximal oxygen consumption possible through the electron transport system after pharmacologically uncoupling oxygen utilization from ATP production to assess the integrity of the ETS independent of energy production. Therefore, ETS $_{\text {max }}$ reflects only the ability the ETS to use electrons to reduce oxygen to water without the need to add high-energy phosphate bonds to produce ATP, a final step in the energy-production pathway that normally helps to regulate ETS activity. Mitochondrial respiration was then inhibited by adding the ETS complex IV inhibitor, sodium azide, in 5-10 mM increments, followed by the ETS complex III inhibitor, antimycin A, in $5 \mu \mathrm{L}$ increments until no further decrease in oxygen consumption was observed. The residual oxygen flux reflective of nonmitochondrial respiration was subtracted from other respiration values. Respiration supporting mitochondrial ATP synthesis (ATP-linked respiration) was calculated as routine minus LEAK 
medRxiv preprint doi: https://doi.org/10.1101/2021.09.15.21263652; this version posted October 29, 2021. The copyright holder for this preprint (which was not certified by peer review) is the author/funder, who has granted medRxiv a license to display the preprint in perpetuity.

All rights reserved. No reuse allowed without permission.

respiration. Spare respiratory capacity $(\mathrm{SRC})$, calculated as $\mathrm{ETS}_{\max }$ minus routine respiration, is the mitochondrial bioenergetic reserve available for cells to produce ATP in response to a stressinduced increase in metabolic demand.

\section{$\underline{\text { Functional Assays }}$}

Ex vivo LPS-stimulated whole blood TNF- $\alpha$ was measured by mixing $50 \mathrm{ml}$ heparinized whole blood with $500 \mathrm{ml}(250 \mathrm{pg})$ of phenol-extracted LPS from Salmonella enterica abortus equi (Sigma-Aldrich, L5886) within 60 to 90 minutes of blood collection as previously described

${ }^{8}$. The sample was then incubated for 4 hours at $37^{\circ} \mathrm{C}$, followed by centrifugation at $1,000 \mathrm{~g}$ for 5 minutes. The supernatant was stored at $-80^{\circ} \mathrm{C}$ for batched analysis. TNF- $\alpha$ was measured, in duplicate, using an enzyme-linked immunosorbent assay kit (Invitrogen KHC3011C).

Immunoparalysis was a priori defined as LPS-stimulated TNF- $\alpha$ less than 200pg/ml. Monocyte HLA-DR was measured using a whole-blood lysis technique. The sample was then stained with labeled anti-HLA-DR and anti-CD14 antibodies and the percentage of HLA-DR-positive cells among the CD-14 positive population was determined using flow cytometry.

\section{$\underline{\text { Plasma Proteomics }}$}

Interleukin (IL)-4, IL-6, IL-10, IL-18, IL-1RA, and Interferon (IFN)- $\gamma$ were measured using commercially available assays (Cytokine Human Magnetic 30-Plex Panel, Invitrogen/ThermoFisher Scientific, Waltham, MA; Human Magnetic Luminex Assay and CRP DuoSet ELISA, R\&D Systems, Minneapolis, MN). All samples were run in duplicate. FLUOstar software ${ }^{\circledR}$ (Ortenberg, Germany) was used to calculate standard curves for each analyte. To ensure accuracy and precision, the standard curve was required to have $r^{2}>95 \%$, and 
medRxiv preprint doi: https://doi.org/10.1101/2021.09.15.21263652; this version posted October 29, 2021. The copyright holder for this preprint (which was not certified by peer review) is the author/funder, who has granted medRxiv a license to display the preprint in perpetuity.

All rights reserved. No reuse allowed without permission.

the results from mock samples were required to be within the $95 \%$ confidence interval of the expected range provided by the manufacturer.

\section{$\underline{\text { Plasma Metabolomics }}$}

Water-soluble plasma metabolites were analyzed by liquid chromatography-mass spectrometry, using the protocol previously described by Lu et al. ${ }^{22}$ Briefly, $200 \mathrm{ml}$ ice-cold methanol was added to each $50 \mu \mathrm{l}$ plasma sample, vortexed for 10 seconds, and then transferred to a $-20^{\circ} \mathrm{C}$ for 20 minutes. Samples were centrifuged at $13,200 \mathrm{rpm}$ for 15 minutes. The supernatant was extracted and then dried under nitrogen flow and reconstituted in 1ml LC-MS grade water. Samples were analyzed on two separate instrument platforms to cover both positive charged and negative charged metabolites.

Negative charged metabolites were analyzed via reverse-phase ion-pairing chromatography coupled to an Exactive orbitrap mass spectrometer (ThermoFisher Scientific, San Jose, CA). The mass spectrometer was operated in negative ion mode with resolving power of 100,000 at $\mathrm{m} / \mathrm{z} 200$, scanning range being $\mathrm{m} / \mathrm{z} 75-1000$. The LC separation was achieved using a Synergy Hydro-RP column $(100 \mathrm{~mm} \times 2 \mathrm{~mm}, 2.5 \mu \mathrm{m}$ particle size, Phenomenex, Torrance, CA) with a flow rate of $200 \mu \mathrm{L} / \mathrm{min}$. The LC gradient was $0 \mathrm{~min}, 0 \% \mathrm{~B} ; 2.5 \mathrm{~min}, 0 \%$ B; $5 \min , 20 \%$ B; $7.5 \min , 20 \%$ B; $13 \min , 55 \%$ B; $15.5 \min , 95 \%$ B; $18.5 \min , 95 \%$ B; $19 \min$, 0\% B; $25 \mathrm{~min}, 0 \% \mathrm{~B}$. Solvent A is $97: 3$ water:methanol with $10 \mathrm{mM}$ tributylamine and $15 \mathrm{mM}$ acetic acid; solvent $B$ is methanol.

Positive charged metabolites were analyzed on a Q Exactive Plus mass spectrometer coupled to Vanquish UHPLC system (ThermoFisher Scientific, San Jose, CA). The mass

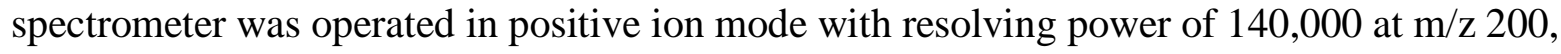


medRxiv preprint doi: https://doi.org/10.1101/2021.09.15.21263652; this version posted October 29, 2021. The copyright holder for this preprint (which was not certified by peer review) is the author/funder, who has granted medRxiv a license to display the preprint in perpetuity.

All rights reserved. No reuse allowed without permission.

scanning range being m/z 75-1000. The LC separation was achieved on an Agilent Poroshell 120 Bonus-RP column $(150 \times 2.1 \mathrm{~mm}, 2.7 \mu \mathrm{m}$ particle size $)$. The gradient was $0 \mathrm{~min}, 50 \mu \mathrm{L} / \mathrm{min}$, $0.0 \% \mathrm{~B} ; 6 \mathrm{~min}, 50 \mu \mathrm{L} / \mathrm{min}, 0 \% \mathrm{~B} ; 12 \mathrm{~min}, 200 \mu \mathrm{L} / \mathrm{min}, 70 \% \mathrm{~B} ; 14 \mathrm{~min}, 200 \mu \mathrm{L} / \mathrm{min}, 100 \% \mathrm{~B} ; 18$ min, $200 \mu \mathrm{L} / \min , 100 \% \mathrm{~B} ; 19 \min , 200 \mu \mathrm{L} / \min , 0 \% \mathrm{~B} ; 24 \mathrm{~min}, 200 \mu \mathrm{L} / \mathrm{min}, 0 \% \mathrm{~B} ; 25 \mathrm{~min}, 50$ $\mu \mathrm{L} / \mathrm{min}, 0 \% \mathrm{~B}$. Solvent $\mathrm{A}$ is $10 \mathrm{mM}$ ammonium acetate $+0.1 \%$ acetic acid in $98: 2$ water:acetonitrile and solvent $\mathrm{B}$ is acetonitrile.

For each sample, ion-specific chromatograms for metabolites of interest were identified, and ion counts were abstracted for further analysis. The following metabolites were analyzed in this exploratory analysis: (iso)leucine, alanine, arginine, aspartate, citrate, citrulline, glucosamine, glutamine, histidine, hypoxanthine, lactate, lysine, methionine, phenylalanine, proline, taurine, threonine, valine, 2-dehydrogluconate, 2-hydroxy-glutarate, acetyl-glycine, aketoglutarate, allantoin, asparagine, cystathionine, cysteine, D-glucarate, D-gluconate, fumarate, gluconolactone, glutamate, glycine, glycolate, hippuric acid, homocysteine/ methylcysteine, hydroxyphenylpyruvate, hydroxyproline, indolelactic acid, inosine, kynurenine, malate, Nacetyl-L-alanine, N-acetyl-L-ornithine, phenyllactic acid, pyruvate, serine, trehalose, tyrosine, uric acid, uridine, and xanthine.

\section{$\underline{\text { Statistical Analyses }}$}

Manual flow cytometry gating was completed in Flow $\mathrm{Jo}^{23}$ as detailed above. Data processing and analyses were completed in R Studio. ${ }^{24}$ Extraction and computation was facilitated with the 'dplyr' package. Graphs were plotted with the 'ggplot2' and 'ggpubr' packages. All remaining source code was custom developed. Data are presented as median with interquartile range (IQR) for continuous variables and counts with percentages for categorical 
medRxiv preprint doi: https://doi.org/10.1101/2021.09.15.21263652; this version posted October 29, 2021. The copyright holder for this preprint (which was not certified by peer review) is the author/funder, who has granted medRxiv a license to display the preprint in perpetuity.

All rights reserved. No reuse allowed without permission.

variables. Correlation coefficients were quantified by the Spearman rank correlation coefficient.

Tests of association between continuous versus categorical variables were performed by unpaired Wilcoxon test or Kruskal-Wallis test as appropriate. Association between categorical variables was assessed by Fisher's exact test. All tests were performed in a two-sided manner, using a nominal significance threshold of $p<0.05$ unless otherwise specified, with Bonferroni corrections for analyses that included multiple comparisons.

\section{Results and Discussion}

$\underline{\text { Study patients }}$

Fourteen patients with septic shock and seven non-infected controls were included in our study. Serial blood samples were collected from patients with sepsis and processed for peripheral blood mononuclear cell (PBMC) and plasma; in total, 34 sepsis samples and 7 control samples were obtained. Sepsis samples were collected on days 1-2, 3-5, and 8-14 after sepsis recognition. Control samples were collected from neurosurgical patients in the pediatric intensive care unit (PICU) without infection or organ dysfunction. Detailed descriptions of patient recruitment have been reported previously. ${ }^{25,26}$

Patient demographics, clinical characteristics, and laboratory values are summarized in

Table 1. As expected, sepsis patients had higher illness severity at admission compared to controls as assessed by the Pediatric Index of Mortality-2 (PIM-2) score, ${ }^{17}$ Pediatric Risk of Mortality-III (PRISM-III) score, ${ }^{18}$ and Pediatric Logistic Organ Dysfunction (PELOD) score. ${ }^{19}$ Sepsis patients were also older than controls, but other demographics were similar. Sepsis patients more frequently received endotracheal intubation, vasoactive infusion, and corticosteroids. There was one mortality in the sepsis cohort, none among controls. 
Pediatric sepsis patients exhibit global immunometabolic dysregulation

To quantify differences in lymphocyte subsets between sepsis patients and controls, we first assessed the abundance of key T cell subsets by flow cytometry (Fig. 1a). Compared to controls, the abundance of non-naïve $\mathrm{CD}^{+} \mathrm{T}$ cells was significantly reduced in patients with bacterial sepsis (Fig. 1b). Loss of central memory $\mathrm{CD}^{+}{ }^{+}$T cells $\left(\mathrm{CD} 45 \mathrm{RA}^{-} / \mathrm{CD} 27^{+}\right.$) was the primary driver of this finding; $\mathrm{CD}^{+}{ }^{+} \mathrm{TEMRA}$ cells $\left(\mathrm{CD} 45 \mathrm{RA}^{+} / \mathrm{CD} 27^{-}\right)$were increased in patients with sepsis regardless of pathogen type. Non-naïve $\mathrm{CD}^{+} \mathrm{T}$ cell subsets were similar between sepsis and controls.

We then assessed two global markers of immune dysfunction commonly used in critical care - ex vivo lipopolysaccharide (LPS)-stimulated tumor necrosis factor (TNF)- $\alpha$ production capacity and monocyte human leukocyte antigen (HLA)-DR expression. Immunoparalysis, defined by TNF- $\alpha$ production capacity $<200 \mathrm{pg} / \mathrm{ml},{ }^{8}$ was more common in sepsis patients than controls ( $39 \%$ vs $0 \%, \mathrm{p}=0.08)$. Median monocyte HLA-DR was lower at sepsis onset compared to controls $(75 \%$ vs $92 \%, \mathrm{p}=0.02)$. Cohort heterogeneity by interquartile range decreased on serial samples, and markers of immune dysfunction generally improved with sepsis recovery (Fig. 1c).

We interrogated bulk PBMC mitochondrial function using an Oroboros Oxygraph to measure spare respiratory capacity (SRC), which represents the mitochondrial bioenergetic reserve available for cells to produce ATP in response to stress-induced increase in metabolic demand. ${ }^{27}$ Median SRC was lower at sepsis onset compared to controls (4.0 vs 8.4, p=0.01). SRC improved through time and varied by pathogen type (Fig. 1d). Because the proportion of lymphocyte subsets varied between sepsis patients and controls, we constructed a generalized 
medRxiv preprint doi: https://doi.org/10.1101/2021.09.15.21263652; this version posted October 29, 2021. The copyright holder for this preprint (which was not certified by peer review) is the author/funder, who has granted medRxiv a license to display the preprint in perpetuity.

All rights reserved. No reuse allowed without permission.

linear model which found no association between the relative proportion of CD4+ and CD8+ subsets (naïve, central memory, effector memory, TEMRA) in the PBMC sample and mitochondrial SRC, suggesting that differences in SRC are not confounded by shifts in cell subtypes.

Finally, we assessed plasma metabolites by liquid chromatography-mass spectrometry (Fig. 1e). In this exploratory analysis, some amino acid breakdown products including uridine $(p<0.001)$ and hydroxyphenylpyruvate $(p=0.012)$ and intermediate markers of glucose metabolism including 2-dehydrogluconate $(p<0.001)$ and D-gluconate $(p=0.017)$ were markedly elevated in patients with sepsis across timepoints compared to controls. Conversely, citrulline was decreased in children with sepsis regardless of pathogen $(p<0.001)$; citrulline deficiency has been previously associated with impaired small bowel microcirculation, nitric oxide production, and mortality in sepsis. ${ }^{28,29}$

Taken together, these data demonstrate that pediatric patients with sepsis develop global immunometabolic dysregulation assessed by lower TNF- $\alpha$ production capacity, monocyte HLADR expression, mitochondrial SRC, loss of peripheral non-naïve T cells, and metabolomic abnormalities.

$\underline{\text { T cell abundance and polarization in pediatric sepsis vary by pathogen type }}$

Informed by the heterogeneity of immune abnormalities above, we then stratified $\mathrm{T}$ cell responses by pathogen type. Demographics and severity of illness did not vary by pathogen type. We assessed $\mathrm{CD}^{+} \mathrm{T}$ cell differentiation by measuring intracellular cytokines via flow cytometry after phorbol myristate acetate (PMA)/ionomycin stimulation and identified $\mathrm{CD}^{+}{ }^{\mathrm{T}}$ cell states based on resulting intracellular cytokine expression: Th1 (IFN- $\left.\gamma^{+}\right)$, Th2 (IL13 $\left.{ }^{+}\right)$, Th17 (IL-17 $\left.\alpha^{+}\right)$, 
medRxiv preprint doi: https://doi.org/10.1101/2021.09.15.21263652; this version posted October 29, 2021. The copyright holder for this preprint (which was not certified by peer review) is the author/funder, who has granted medRxiv a license to display the preprint in perpetuity.

All rights reserved. No reuse allowed without permission.

Tfh $\left(\mathrm{IL}-21^{+}\right)$, Treg $\left(\mathrm{FoxP}^{+}\right)$. Th1 cells were reduced in bacterial sepsis and Th2 cells were reduced in viral sepsis compared to controls; Th17, Tfh, and Treg populations did not vary significantly (Fig. 2a). Th1 and Th2 lymphocyte abundance varied widely across serial samples (Fig. 2b). Among patients with bacterial sepsis, the proportion of IL2 $2^{+}$non-naïve CD4 ${ }^{+}$ lymphocytes was lower at sepsis onset compared to controls (Fig. 2c), while the proportion of $\mathrm{CD}^{2} 8^{+}$cells did not vary by pathogen type.

Both pro- and anti-inflammatory plasma cytokines were elevated at sepsis onset compared to controls and varied by pathogen type (Fig. 3). IL-6 and IL-18 were most elevated in bacterial sepsis; IFN- $\gamma$ was low in this subgroup, consistent with reduced CD4+ Th1 cells in this population. IL-10 and IL-1RA were elevated in all sepsis patients, though IL-4 was only elevated in patients with viral sepsis. Among sepsis patients, cytokine values normalized through time as organ dysfunction resolved.

Loss of peripheral non-naïve $\mathrm{CD} 4^{+} \mathrm{T}$ cells is associated with immune dysfunction and $\underline{\text { characteristic immunometabolic dysregulation }}$

In our final analysis, we examined the association between the loss of peripheral nonnaïve $\mathrm{CD}^{+} \mathrm{T}$ cells and markers of immune dysfunction in sepsis patients. The loss of peripheral non-naïve $\mathrm{CD}^{+} \mathrm{T}$ cells is associated with both TNF- $\alpha$ production capacity $(R=0.35, p=0.03)$ and monocyte HLA-DR expression $(R=0.59, p<0.001$; Fig. $4 \mathrm{a})$. The frequency non-naïve $\mathrm{CD} 4^{+} \mathrm{T}$ cells is positively associated with serum IFN- $\gamma$ level $(R=0.57, p<0.001)$ and negatively associated with $\mathrm{CD} 38$ expression on non-naïve $\mathrm{CD}^{+} \mathrm{T}$ cells $(R=-0.48, p=0.001)$, suggesting that loss of peripheral non-naïve $\mathrm{CD}^{+} \mathrm{T}$ cells is associated with decreased $\mathrm{T}$ cell function despite evidence of T cell activation (Fig. 4b). 
medRxiv preprint doi: https://doi.org/10.1101/2021.09.15.21263652; this version posted October 29, 2021. The copyright holder for this preprint (which was not certified by peer review) is the author/funder, who has granted medRxiv a license to display the preprint in perpetuity.

All rights reserved. No reuse allowed without permission.

Finally, we tested the association between plasma metabolites and peripheral non-naïve $\mathrm{CD} 4^{+}$lymphocytes. The loss of peripheral non-naïve $\mathrm{CD} 4^{+} \mathrm{T}$ cells is associated with markers of protein catabolism (hydroxyproline, uridine, phenylalanine; Fig. 4c). Conversely, low glutamine was associated with decreased peripheral non-naïve $\mathrm{CD}^{+} \mathrm{T}$ cells. Glutamine is an essential cofactor for T cell activation, and glutamine depletion has been associated with reduced lymphocyte proliferation, cytokine production, and lymphocyte apoptosis. ${ }^{30,31}$

\section{Conclusions}

We have demonstrated that pediatric sepsis is associated with characteristic immunometabolic dysregulation which vary by pathogen. Adaptive immune dysfunction in sepsis develops during a hyperinflammatory, catabolic state which is characterized by mitochondrial dysfunction and loss of peripheral non-naïve T cells. Heterogeneity in the immune response is partially explained by pathogen type, which appears to influence non-naïve T cell differentiation and function. These alternations in $\mathrm{CD}^{+} \mathrm{T}$ cell subset frequencies which vary by pathogen suggest that the dysregulated adaptive immune response to sepsis may be pathogenspecific.

While these findings are compelling, there are several limitations to our analysis of this pilot data. Our limited number of samples and cohort heterogeneity is susceptible to type II error. Comparison of sepsis patients to controls may bias toward the null if post-surgical patients have a mild inflammatory phenotype which overlaps with the immunometabolic phenotype of sepsis patients. Because steroid exposure was common in sepsis patients regardless of pathogen type, we cannot control for this important covariate in the present study. Because metabolic and mitochondrial measurements were performed in bulk, we cannot conclusively identify the 
medRxiv preprint doi: https://doi.org/10.1101/2021.09.15.21263652; this version posted October 29, 2021. The copyright holder for this preprint (which was not certified by peer review) is the author/funder, who has granted medRxiv a license to display the preprint in perpetuity.

All rights reserved. No reuse allowed without permission.

association between these findings and specific immune cell subsets. Finally, we are unable to account for repeated measures within individuals due to limited sample size.

Through this pilot study, we have established the clinical feasibility of monitoring immune health in pediatric sepsis patients using small volume samples. Immune monitoring in pediatric critical illness is currently limited to inflammatory biomarkers and cytokine analysis. Deep immune profiling and functional testing of patient samples has the potential to identify mechanisms of immune dysfunction in pediatric sepsis, paving the way for personalized immunotherapy in critically ill children.

\section{Acknowledgements}

The authors thank Florin Tuluc and Jennifer Murry from the CHOP Flow Cytometry

Core Laboratory and Fang Chen and Natalka Kengle from the Center for Immunotherapies at the University of Pennsylvania for their contributions to this study. 


\section{REFERENCES}

1. Rudd KE, Johnson SC, Agesa KM, et al. Global, regional, and national sepsis incidence and mortality, 1990-2017: analysis for the Global Burden of Disease Study. The Lancet. 2020;395(10219):200-211.

2. Goldstein B, Giroir B, Randolph A, International Consensus Conference on Pediatric S. International pediatric sepsis consensus conference: definitions for sepsis and organ dysfunction in pediatrics. Pediatr Crit Care Med. 2005;6(1):2-8.

3. Singer M, Deutschman CS, Seymour CW, et al. The Third International Consensus Definitions for Sepsis and Septic Shock (Sepsis-3). JAMA. 2016;315(8):801-810.

4. Weiss SL, Peters MJ, Alhazzani W, et al. Surviving Sepsis Campaign International Guidelines for the Management of Septic Shock and Sepsis-Associated Organ Dysfunction in Children. Pediatr Crit Care Med. 2020;21(2):e52-e106.

5. Lindell RB, Nishisaki A, Weiss SL, Traynor DM, Fitzgerald JC. Risk of Mortality in Immunocompromised Children With Severe Sepsis and Septic Shock. Crit Care Med. 2020 .

6. Lindell RB, Gertz SJ, Rowan CM, et al. High Levels of Morbidity and Mortality Among Pediatric Hematopoietic Cell Transplant Recipients With Severe Sepsis: Insights From the Sepsis PRevalence, OUtcomes, and Therapies International Point Prevalence Study. Pediatr Crit Care Med. 2017;18(12):1114-1125.

7. Hotchkiss RS, Opal SM. Activating Immunity to Fight a Foe - A New Path. $N$ Engl J Med. 2020;382(13):1270-1272.

8. Hall MW, Knatz NL, Vetterly C, et al. Immunoparalysis and nosocomial infection in children with multiple organ dysfunction syndrome. Intensive Care Med. 2011;37(3):525-532.

9. Wong HR, Freishtat RJ, Monaco M, Odoms K, Shanley TP. Leukocyte subset-derived genomewide expression profiles in pediatric septic shock. Pediatr Crit Care Med. 2010;11(3):349-355.

10. Muszynski JA, Nofziger R, Greathouse K, et al. Early adaptive immune suppression in children with septic shock: a prospective observational study. Crit Care. 2014;18(4):R145.

11. Muszynski JA, Nofziger R, Greathouse K, et al. Innate immune function predicts the development of nosocomial infection in critically injured children. Shock. 2014;42(4):313-321.

12. Muszynski JA, Nofziger R, Moore-Clingenpeel M, et al. Early Immune Function and Duration of Organ Dysfunction in Critically III Children with Sepsis. Am J Respir Crit Care Med. 2018;198(3):361-369. 
medRxiv preprint doi: https://doi.org/10.1101/2021.09.15.21263652; this version posted October 29, 2021. The copyright holder for this preprint

(which was not certified by peer review) is the author/funder, who has granted medRxiv a license to display the preprint in perpetuity.

All rights reserved. No reuse allowed without permission.

13. Hall MW, Geyer SM, Guo CY, et al. Innate immune function and mortality in critically ill children with influenza: a multicenter study. Crit Care Med. 2013;41(1):224-236.

14. Delano MJ, Ward PA. Sepsis-induced immune dysfunction: can immune therapies reduce mortality? J Clin Invest. 2016;126(1):23-31.

15. Monneret G, Gossez M, Aghaeepour N, Gaudilliere B, Venet F. How Clinical Flow Cytometry Rebooted Sepsis Immunology. Cytometry A. 2019;95(4):431-441.

16. Gossez M, Rimmele T, Andrieu T, et al. Proof of concept study of mass cytometry in septic shock patients reveals novel immune alterations. Sci Rep. 2018;8(1):17296.

17. Slater A, Shann F, Pearson G, Paediatric Index of Mortality Study G. PIM2: a revised version of the Paediatric Index of Mortality. Intensive Care Med. 2003;29(2):278-285.

18. Pollack MM, Patel KM, Ruttimann UE. PRISM III: an updated Pediatric Risk of Mortality score. Crit Care Med. 1996;24(5):743-752.

19. Leteurtre S, Martinot A, Duhamel A, et al. Validation of the paediatric logistic organ dysfunction (PELOD) score: prospective, observational, multicentre study. Lancet. 2003;362(9379):192-197.

20. Weiss SL, Selak MA, Tuluc F, et al. Mitochondrial dysfunction in peripheral blood mononuclear cells in pediatric septic shock. Pediatr Crit Care Med. 2015;16(1):e4-e12.

21. Pesta D, Gaiger E. High-Resolution Respirometry: OXPHOS Protocols for Human Cells and Permeabilized Fibers form Small Biopsies of Human Muscle. In: AJ PCaM, ed. Mitochochondrial Bioenergetics: Methods and Protocols. Vol 810. Springer Science+Business Media; 2012:25-58.

22. Lu W, Clasquin MF, Melamud E, Amador-Noguez D, Caudy AA, Rabinowitz JD. Metabolomic analysis via reversed-phase ion-pairing liquid chromatography coupled to a stand alone orbitrap mass spectrometer. Anal Chem. 2010;82(8):3212-3221.

23. FlowJo Software v10.8 [computer program]. Ashland, OR: Becton, Dickinson and Company; 2021.

24. RStudio: Integrated Development for $R$ [computer program]. Boston, MA: RStudio, PBC; 2020.

25. Weiss SL, Zhang D, Bush J, et al. Persistent Mitochondrial Dysfunction Linked to Prolonged Organ Dysfunction in Pediatric Sepsis. Crit Care Med. 2019.

26. Weiss SL, Zhang D, Bush J, et al. Mitochondrial Dysfunction is Associated With an Immune Paralysis Phenotype in Pediatric Sepsis. Shock. 2020;54(3):285-293.

27. Brand MD, Nicholls DG. Assessing mitochondrial dysfunction in cells. Biochem J. 2011;435(2):297-312. 
medRxiv preprint doi: https://doi.org/10.1101/2021.09.15.21263652; this version posted October 29, 2021. The copyright holder for this preprint

(which was not certified by peer review) is the author/funder, who has granted medRxiv a license to display the preprint in perpetuity.

All rights reserved. No reuse allowed without permission.

28. Wijnands KA, Castermans TM, Hommen MP, Meesters DM, Poeze M. Arginine and citrulline and the immune response in sepsis. Nutrients. 2015;7(3):1426-1463.

29. Weiss SL, Haymond S, Ralay Ranaivo H, et al. Evaluation of asymmetric dimethylarginine, arginine, and carnitine metabolism in pediatric sepsis. Pediatr Crit Care Med. 2012;13(4):e210-218.

30. Cruzat V, Macedo Rogero M, Noel Keane K, Curi R, Newsholme P. Glutamine: Metabolism and Immune Function, Supplementation and Clinical Translation. Nutrients. $2018 ; 10(11)$.

31. van der Windt GJ, Pearce EL. Metabolic switching and fuel choice during T-cell differentiation and memory development. Immunol Rev. 2012;249(1):27-42. 
Table 1. Characteristics of sepsis patients and controls at PICU admission

\begin{tabular}{|c|c|c|c|}
\hline Variable & $\begin{array}{c}\text { Sepsis } \\
\text { Patients } \\
(n=14)\end{array}$ & $\begin{array}{c}\text { PICU } \\
\text { Controls } \\
(n=7)\end{array}$ & $p^{a}$ \\
\hline Age in years, median [IQR] & $15.9[14.6-17.6]$ & $10.4[10.0-14.6]$ & 0.02 \\
\hline Male sex, n (\%) & $6(43)$ & $6(86)$ & 0.16 \\
\hline Non-Caucasian race, $\mathrm{n}(\%)$ & $9(64)$ & $3(43)$ & 0.40 \\
\hline $\begin{array}{l}\text { Indication for PICU admission, } \mathrm{n}(\%) \\
\text { Sepsis, bacterial etiology } \\
\text { Sepsis, viral etiology } \\
\text { Sepsis, culture negative / unknown etiology } \\
\text { Neurosurgery }\end{array}$ & $\begin{array}{l}7(50) \\
4(29) \\
3(21) \\
--\end{array}$ & $\begin{array}{c}-- \\
-- \\
-- \\
7(100)\end{array}$ & -- \\
\hline PIM-2 probability of death, median [IQR] & $4.0[1.0-5.9]$ & $0.2[0.1-1.1]$ & 0.01 \\
\hline PRISM-III score, median [IQR] & $12.0[7.8-14.2]$ & $2.0[0.0-3.0]$ & $<0.001$ \\
\hline PELOD score, median [IQR] & $12.0[10.3-20.8]$ & $0.0[0.0-0.0]$ & $<0.001$ \\
\hline Steroid exposure, n (\%) & $6(43)$ & $0(0)$ & 0.12 \\
\hline Endotracheal intubation, n (\%) & $8(57)$ & $0(0)$ & 0.01 \\
\hline Vasoactive infusion, $\mathrm{n}(\%)$ & $7(50)$ & $0(0)$ & 0.01 \\
\hline PICU mortality, n (\%) & $1(7)$ & $0(0)$ & -- \\
\hline
\end{tabular}

${ }^{a}$ Wilcoxon rank-sum test for continuous variables; Fisher's exact test for categorical variables. 

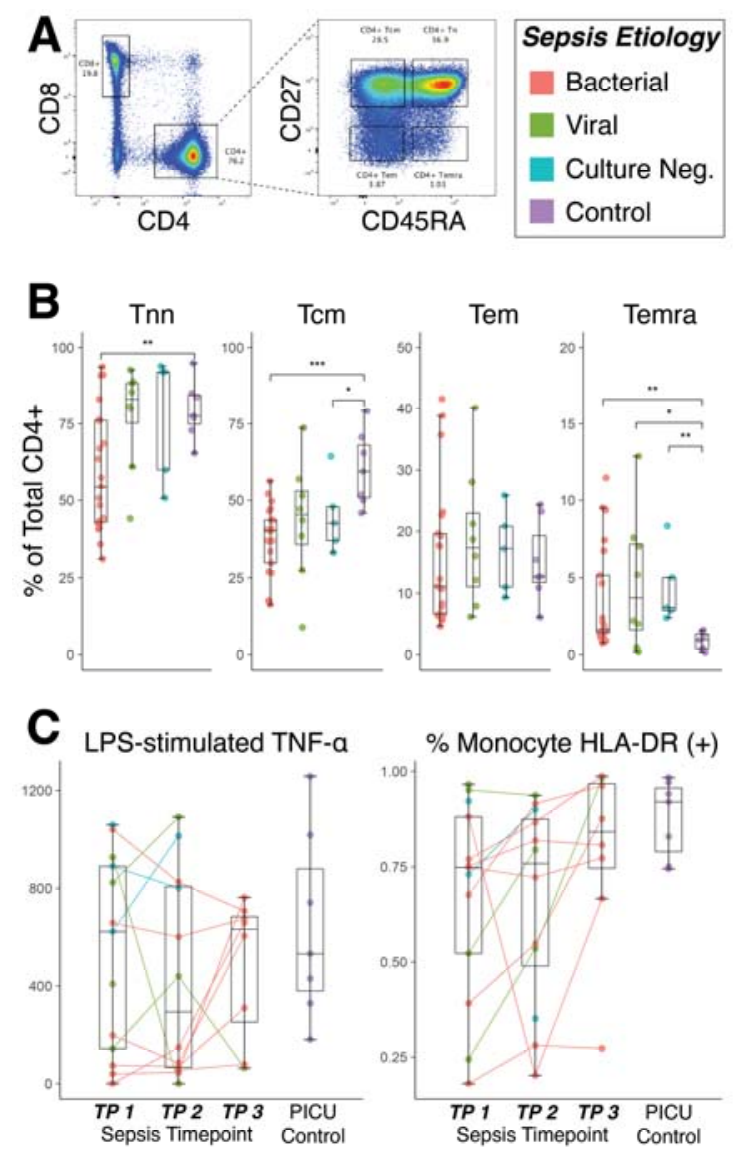

D Mitochondrial Spare Respiratory Capacity (SRC)
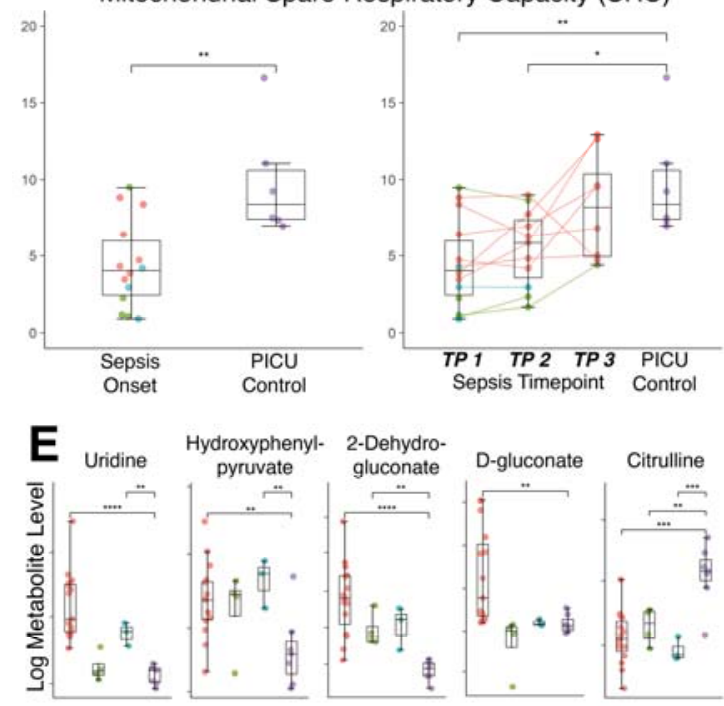

Figure 1. Immunometabolic dysregulation in pediatric sepsis patients. Panel A: $\mathrm{CD}^{+} \mathrm{T}$ cell gating strategy. Panel B: Relative abundance of T cell subsets differ between sepsis and control and are most pronounced for patients with bacterial sepsis. Panel C: Immune dysfunction at sepsis onset resolves in some patients on longitudinal sampling. Panel D: Mitochondrial function in sepsis patients improves through time. Panel E: Metabolomics findings reflect increased reactive oxygen species, amino acid breakdown products, and citrulline deficiency. 

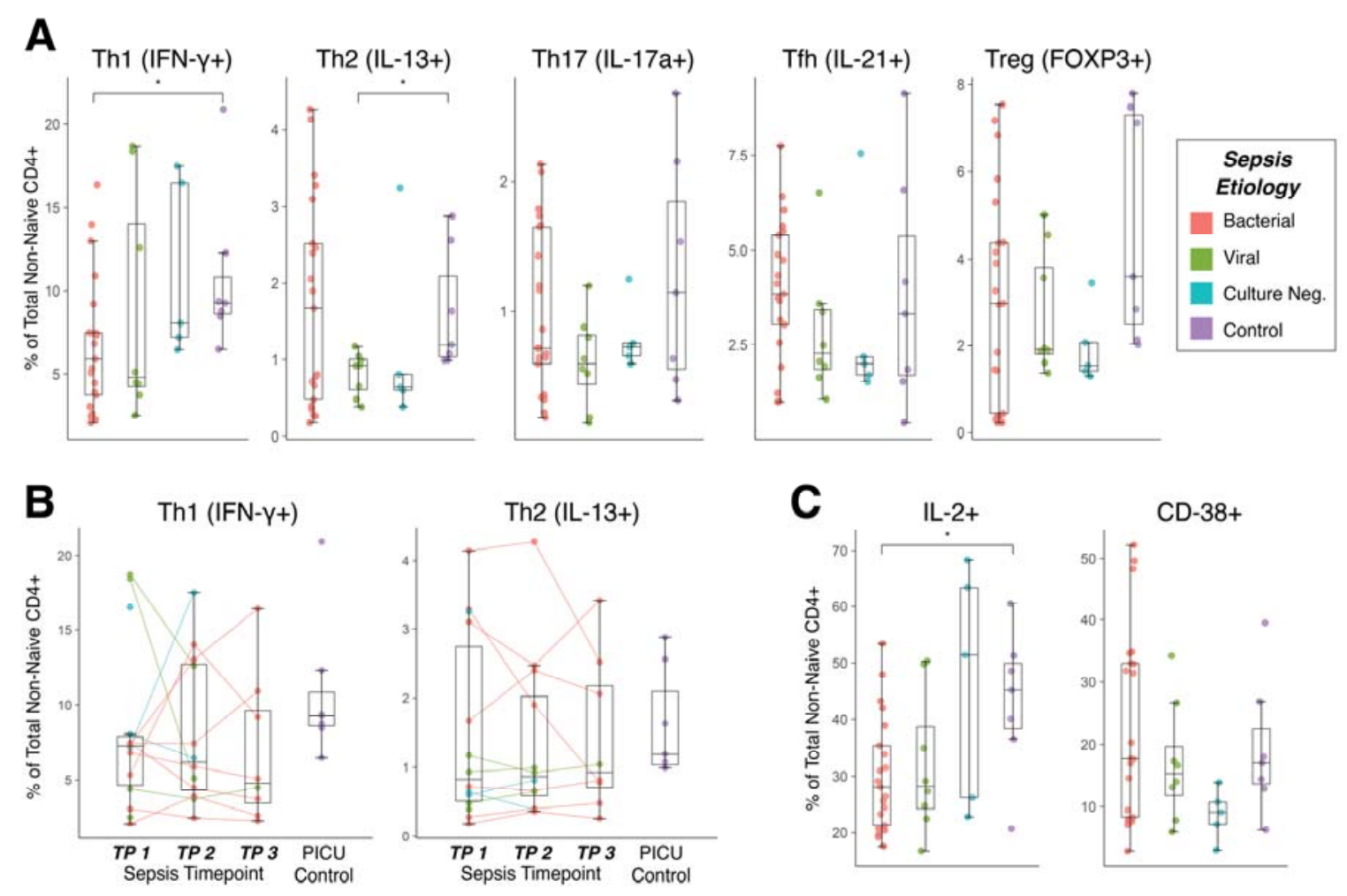

Figure 2. $T$ cell activation and differentiation varies by pathogen type in pediatric sepsis patients. Panel A: Differentiation of $\mathrm{CD} 4^{+} \mathrm{T}$ cells exhibits substantial heterogeneity which is partially explained by pathogen type. Panel B: In longitudinal sampling, Th1 and Th2 lymphocyte abundance varied within some patients but was constant in others. Panel C: Patients with bacterial sepsis had fewer IL-2+ lymphocytes than controls. 
medRxiv preprint doi: https://doi.org/10.1101/2021.09.15.21263652; this version posted October 29, 2021. The copyright holder for this preprint (which was not certified by peer review) is the author/funder, who has granted medRxiv a license to display the preprint in perpetuity.

All rights reserved. No reuse allowed without permission.


Figure 3. Plasma cytokine levels vary by pathogen type in pediatric sepsis patients. 

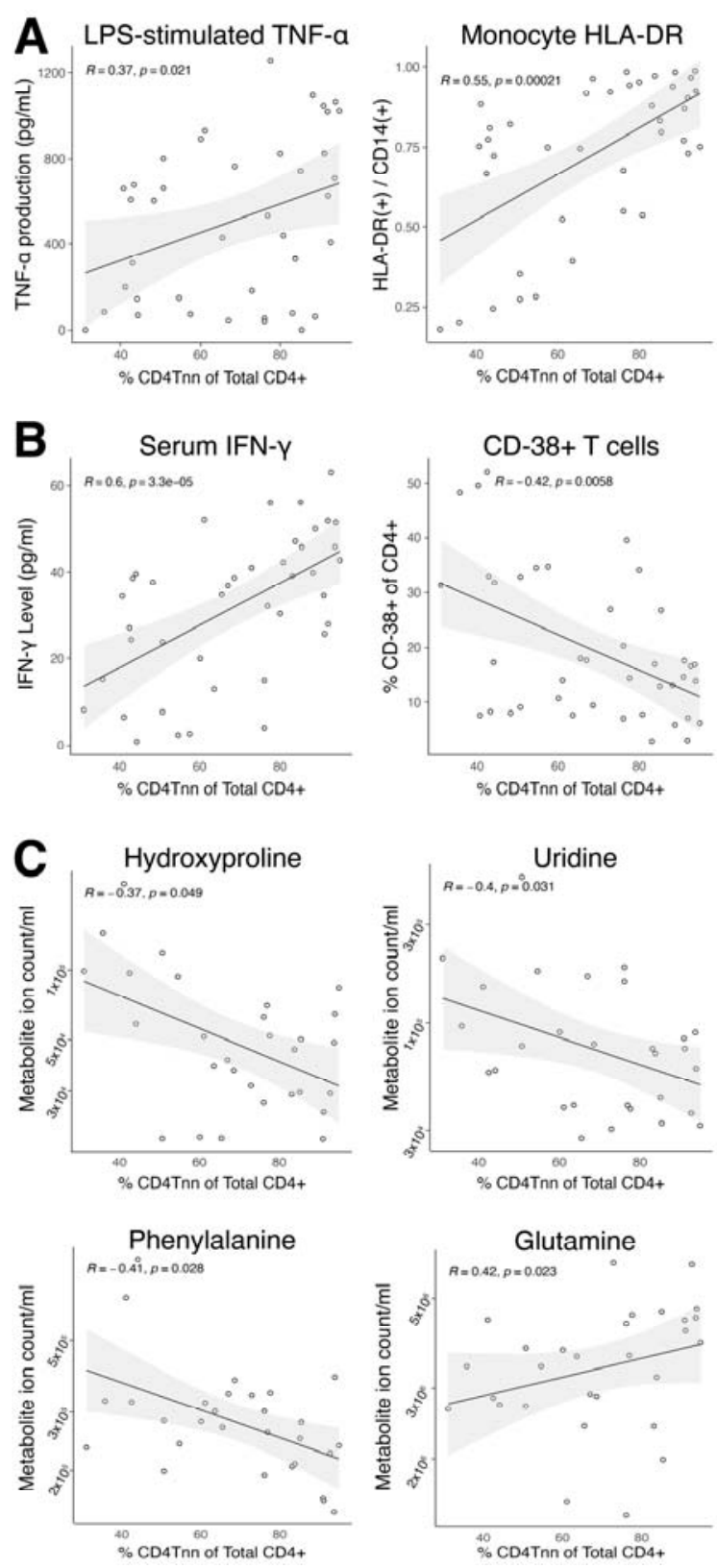

Figure 4. Loss of peripheral non-naïve $\mathrm{CD4}^{+} \mathrm{T}$ cells is associated with functional, proteomic, and metabolomic abnormalities in pediatric sepsis patients. Panel A: The loss of peripheral non-naïve $\mathrm{CD} 4^{+} \mathrm{T}$ cells is associated with both TNF- $\alpha$ production capacity and monocyte HLA-DR expression. Panel B: Non-naïve CD4 ${ }^{+} \mathrm{T}$ cells are positively associated with serum IFN- $\gamma$ level and negatively associated with CD38 expression, suggesting that loss of peripheral non-naïve $\mathrm{CD} 4^{+} \mathrm{T}$ cells is associated with decreased $\mathrm{T}$ cell function. Panel C: Loss of peripheral non-naïve $\mathrm{CD}^{+}$lymphocytes is associated with several markers of protein catabolism and low plasma glutamine levels. 